\title{
Perbandingan Latihan Kontinu Intensitas Sedang dan Latihan Interval Intensitas Tinggi terhadap Kontrol Glukosa Darah
}

\author{
Nadhila Atsari, Hermawan Susanto, Raden Argarini \\ ${ }^{1}$ Fakultas Kedokteran Universitas Airlangga Surabaya, ${ }^{2}$ Divisi Endokrin dan Metabolik Departemen Ilmu \\ Penyakit Dalam Fakultas Kedokteran Universitas Airlangga/RSUD Dr.Soetomo Surabaya, ${ }^{3}$ Departemen Ilmu Faal \\ Fakultas Kedokteran Universitas Airlangga Surabaya
}

\begin{abstract}
Abstrak
Pencegahan diabetes melitus tipe 2 (DMT2) dapat dilakukan dengan memperbanyak latihan fisik. Latihan kontinu intensitas sedang (LKIS) dan latihan interval intensitas tinggi (LIIT) diketahui dapat meningkatkan kontrol glukosa pada orang dengan resistensi insulin/DMT2. Tujuan penelitian ini adalah membandingkan efek LIIT dan LKIS pada orang sehat terhadap kontrol glukosa darah, yaitu glukosa darah puasa (GDP) dan tes toleransi glukosa oral (TTG0). Laki-laki $(\mathrm{n}=27)$, usia $(20,07 \pm 0,62)$, IMT $(23,94 \pm 3,59) \mathrm{kg} / \mathrm{m}^{2}$ berpartisipasi dalam kelompok LKIS, LIIT, atau kontrol. Latihan Ergocycle dilakukan $3 \mathrm{sesi} / \mathrm{minggu}$ selama 4 minggu; LKIS dengan total durasi 46 menit/sesi (intensitas sedang 50-60\% denyut jantung cadangan [HRR] selama 40 menit); LIIT dengan total durasi 24 menit/ sesi (6 siklus; 2 menit intensitas tinggi $80-90 \%$ HRR +1 menit intensitas sedang 50-60\% HRR). Kontrol tidak mendapat intervensi latihan. GDP dan TTGO (120' setelah beban glukosa) diperiksa 3 hari sebelum dan setelah program latihan. Hasil penelitian menunjukkan GDP menurun pada semua kelompok, tetapi hanya LKIS yang menunjukkan penurunan signifikan $(p=0,048)$. TTGO ditemukan tidak berubah di semua kelompok $(p>0,05)$. LKIS memiliki potensi untuk meningkatkan kontrol glukosa darah pada subjek dewasa muda. Penelitian lanjutan dengan modifikasi dosis latihan diperlukan untuk mengetahui efek LIIT lebih lanjut. [MKB. 2016;48(4):194-9]
\end{abstract}

Kata kunci: kontrol glukosa darah, latihan interval intensitas tinggi, latihan kontinu intensitas sedang

\section{Comparison of Moderate Intensity Continuous Training and High Intensity Interval Training on Blood Glucose Control}

\begin{abstract}
Type 2 diabetes mellitus (T2DM) can be prevented by intensive physical exercise/training. Moderate intensity continuous training (MICT) and high intensity interval training (HIIT) are known to improve glucose control in people with insulin resistance and T2DM. The purpose of this study was to compare the effects of MICT and HIIT in healthy people on blood glucose levels, which was measured through fasting blood glucose (FBG) and oral glucose tolerance test (OGTT). Healthy men ( $\mathrm{n}=27)$, aged $(20.07 \pm 0.62)$, BMI $(23.94 \pm 3.59) \mathrm{kg} / \mathrm{m} 2$ participated in either MICT, HIIT, or Control group ( $\mathrm{n}=9$ each group). Ergocycle exercise were performed 3 times/week for 4 weeks; MICT with a total duration of 46 minutes/session (moderate intensity $50-60 \%$ heart rate reserve [HRR]) for 40 minutes); HIIT with a total duration of 24 minutes/session ( 6 cycles; 2 mins high intensity 80-90\% HRR +1 min moderate intensity 50-60\% HRR). Controls did not receive any programmed training. FBG and OGTT (120' after glucose load) were checked 3 days before and after the exercise program. This study found that FBG decreased in all groups but only the MICT group showed a significant reduction $(\mathrm{p}=0.048)$. OGTT was found unaltered in all groups ( $\mathrm{p}>0.05$ ). MICT has the potential to improve blood glucose control in healthy young adult subjects. However, further research with exercise dose modification is required to elucidate the effects of HIIT. [MKB. 2016;48(4):194-9]
\end{abstract}

Key words: Blood glucose control, high intensity interval training, moderate intensity continuous training

Korespondensi: Nadhila Atsari, dr., Fakultas Kedokteran Universitas Airlangga, Jalan Airlangga No. 4-6, Gubeng, Airlangga, Gubeng, Surabaya, Jawa Timur mobile 085726153315, e-mail atsarinadhila@gmail.com 


\section{Pendahuluan}

Prediabetes dan diabetes melitus tipe 2 (DMT2) merupakan gangguan metabolik kronis yang prevalensinya terus meningkat secara global dan mempunyai kecenderungan untuk timbul lebih pada usia muda. ${ }^{1,2}$ Perjalanan penyakit DMT2 dapat dicegah atau diperlambat dengan modifikasi gaya hidup, salah satunya dengan cara memperbanyak latihan fisik. ${ }^{3}$ Latihan fisik yang direkomendasikan oleh Asosiasi Diabetes Amerika ialah latihan aerobik intensitas sedang selama minimal 150 menit/minggu. ${ }^{1}$ Latihan fisik ini berupa latihan kontinu intensitas sedang (LKIS) yang kerap dikeluhkan karena membutuhkan komitmen waktu yang panjang sehingga kurang diminati masyarakat yang sibuk dan tidak mempunyai banyak waktu luang. ${ }^{4}$ Oleh karena itu, diperlukanlah metode latihan fisik yang lebih efisien waktu tetapi memiliki pengaruh yang sama baiknya untuk memperkuat fungsi metabolik tubuh supaya pencegahan DMT2 dapat semakin ditingkatkan. Salah satu fungsi metabolik yang erat kaitannya dengan pencegahan DMT2 adalah kontrol glukosa yang optimal.

Dalam satu dekade terakhir, latihan interval intensitas tinggi (LIIT) semakin banyak diteliti. LIIT merupakan latihan fisik berdurasi pendek yang terdiri atas beberapa siklus latihan dengan intensitas tinggi yang diselingi dengan periode istirahat pada intensitas lebih rendah. LIIT berbeda dengan LKIS dikarenakan sifatnya yang lebih anaerobik dan memanfaatkan pemecahan glikogen otot sebagai sumber energi utamanya. ${ }^{5}$ Penelitian-penelitian sebelumnya menemukan pengaruh LIIT selama 2 (dua) minggu dapat meningkatkan kontrol glukosa darah pada subjek resistensi insulin/DMT2 melalui peningkatan protein glucose transporter GLUT-4 dan kapasitas mitokondria otot, serta meningkatkan toleransi glukosa dan sensitivitas insulin pada subjek dewasa muda. ${ }^{6-8}$ LIIT selama delapan minggu berpengaruh meningkatkan kapasitas metabolik pada subjek berusia paruh baya. ${ }^{9}$ Berdasarkan penelitian-penelitian sebelumnya, LIIT dengan berbagai dosis latihan memiliki tendensi untuk menjadi alternatif latihan fisik yang efektif dan efisien untuk meningkatkan kebugaran dan fungsi metabolik pada beragam kriteria subjek, tetapi belum banyak data yang diperoleh dengan membandingkan pengaruh kronis LIIT dan LKIS dalam jangka waktu pemberian intervensi selama empat minggu pada subjek yang sehat, terutama pada subjek orang Indonesia. Tujuan penelitian ini adalah mengetahui perbandingan pengaruh LIIT dan juga LKIS terhadap kontrol glukosa darah yang diperiksa melalui glukosa darah puasa (GDP) dan tes toleransi glukosa oral (TTGO) pada subjek dewasa muda dan sehat dengan kebiasaan latihan fisik minimal.

\section{Metode}

Rancangan pada penelitian ini adalah penelitian eksperimental murni dengan pre-test dan posttest dan adanya kelompok kontrol. Penelitian ini melibatkan 27 sampel dari populasi mahasiswa S1 Pendidikan Dokter Fakultas Kedokteran Universitas Airlangga (FK Unair). Kriteria inklusi sampel ialah jenis kelamin laki-laki; sehat tanpa penyakit kardiometabolik yang diketahui dari anamnesis, pemeriksaan spirometri, dan elektrokardiografi; tidak terlibat pada program latihan fisik di luar penelitian; dan bersedia mengikuti penelitian dengan menandatangani persetujuan atau informed consent. Sampel dieksklusi dari penelitian apabila tidak mampu mencapai intensitasnya $70 \%$ denyut jantung maksimal $\left(\mathrm{HR}_{\max }\right)$, tingkat partisipasi kurang dari $80 \%$, dan bila mengonsumsi obat-obatan yang dapat memengaruhi kadar glukosa seperti steroid dan obat yang mengandung hormon. Sampel dialokasikan secara acak ke dalam tiga kelompok, yaitu kelompok LKIS, LIIT, atau kontrol. Subjek pada kelompok LKIS dan LIIT mendapat intervensi berupa program latihan sebanyak 12 kali yang tersebar dalam empat minggu (3 kali/minggu selama empat minggu), sedangkan kelompok kontrol tidak mendapat intervensi program latihan. Subjek penelitian tidak mendapat intervensi diet apapun, tetapi diinstruksikan untuk tidak mengubah kebiasaan makan dan istirahat sehari-hari selama program latihan/selama empat minggu. Subjek diminta absen dari latihan fisik yang berat, tidur terlalu malam, dan mengonsumsi kafein sehari sebelum pengambilan data. Penelitian ini telah dinyatakan laik etik oleh Komite Etik Penelitian Kesehatan FK Unair.

LKIS dan LIIT merupakan latihan berupa mengayuh sepeda statis Ergocycle Monark 828E dan mempergunakan pengukur denyut jantung (Polar RS400"') dengan dosis latihan mengacu pada penelitian Parpa dkk. ${ }^{10}$ yang agak sedikit dimodifikasi. Intensitas latihan berdasarkan denyut nadi cadangan (heart rate reserve - HRR) yang kemudian menentukan zona latihan dengan rumus sebagaimana berikut. 
Tabel 1 Karakteristik Subjek

\begin{tabular}{lcccc}
\hline & LKIS & LIIT & Kontrol & p \\
\hline N (laki-laki) & 9 & 9 & 9 & - \\
Usia (tahun) & $20,11 \pm 0,33$ & $19,89 \pm 0,78$ & $20,22 \pm 0,67$ & 0,52 \\
Berat badan (kg) & $64,33 \pm 11,80$ & $71,00 \pm 14,81$ & $67,67 \pm 7,86$ & 0,50 \\
Tinggi badan (m) & $168,39 \pm 8,31$ & $166,67 \pm 5,72$ & $168,78 \pm 4,21$ & 0,75 \\
IMT $\left(\mathrm{kg} / \mathrm{m}^{2}\right)$ & $22,60 \pm 3,05$ & $25,48 \pm 4,74$ & $23,73 \pm 2,33$ & 0,24 \\
\hline
\end{tabular}

Rumus HRR: $\left[\mathrm{HR}_{\max }-\left(\mathrm{HR}_{\mathrm{rest}}\right)\right]$ : [(220-Usia) - (HR saat istirahat)]

Zona latihan: $\mathrm{HRR} x$ intensitas $(\%)+\mathrm{HR}_{\text {rest }}$

Latihan diawali pemanasan dan diakhiri pendinginan selama tiga menit masing-masing pada intensitas 30\% HRR. LKIS berupa mengayuh Ergocycle secara konstan pada intensitas sedang 50-60\% HRR selama 40 menit, sedangkan LIIT berupa latihan enam siklus yang terdiri dari 2 menit intensitas tinggi $80-90 \%$ HRR +1 menit intensitas sedang 50-60\% HRR per siklus. Total konsumsi waktu LKIS adalah 46 menit/sesi sedangkan LIIT berdurasi 24 menit/sesi.

Pengambilan data dari glukosa darah puasa (GDP) dan tes toleransi glukosa oral (TTGO) dilakukan tiga hari sebelum program latihan dimulai (pre-test) dan tiga hari sesudah program latihan usai (post-test) pada kelompok LKIS dan LIIT untuk menghindari pengaruh akut dari latihan terakhir. Pre-test dan post-test kelompok kontrol dilakukan dengan jeda empat minggu. Pemeriksaan GDP dan TTGO memakai strip dan glucometer ACCU-CHEK ${ }^{\circledR}$-Performa yang telah terbukti hasilnya paling mendekati pemeriksaan glukosa di laboratorium dan juga telah lolos quality control. ${ }^{12}$ GDP diperiksa pagi hari setelah berpuasa selama 8-9 jam dengan sampel darah kapiler yang diaplikasikan pada strip glukosa ACCU-CHEK ${ }^{\circledR}$-Performa. Setelah itu, subjek meminum beban glukosa sebanyak 75 gram yang dilarutkan dalam $250 \mathrm{~mL}$ air dan melanjutkan puasa. Pemeriksaan kadar glukosa TTGO dilakukan 120 menit setelah pemberian beban glukosa. Semua data dipresentasikan dalam rata-rata \pm standar deviasi ( $\bar{x} \bar{x} \pm$ SD) dan kadar glukosa dilaporkan dalam satuan mg/ dL. Data dianalisis dengan interval kepercayaan 95\% dan $\alpha=0,05$ melalui uji normalitas Shapiro Wilk, uji homogenitas, ANOVA satu arah, dan uji t-berpasangan menggunakan perangkat lunak IBM SPSS statistics for windows versi 20.0.

\section{Hasil}

Persetujuan menjadi subjek penelitian diperoleh dari 27 subjek yang memenuhi kriteria inklusi dan mengikuti penelitian dengan partisipasi pada program latihan LIIT atau LKIS $\geq 80 \%$. Usia rata-rata 27 subjek adalah $(20,07 \pm 0,62)$ tahun dengan indeks massa tubuh $(23,94 \pm 3,59) \mathrm{kg} / \mathrm{m}^{2}$ dan terbagi secara acak ke dalam tiga kelompok 9 orang masing-masing dengan karakteristik tersaji pada tabel 1. Hasil GDP dan TTGO saat pre-test dan post-test tersaji pada tabel 2.

Tidak didapatkan perbedaan GDP maupun TTGO rata-rata saat pre-test maupun post-test yang bermakna di antara ketiga kelompok melalui uji ANOVA satu arah ( $p>0.05)$. Nilai GDP post-test cenderung menurun dibanding dengan saat pre-test pada ketiga kelompok, akan tetapi penurunan yang bermakna hanya terdapat pada kelompok LKIS.

Tabel 2 Hasil GDP dan TTGO Pre-test Post-test

\begin{tabular}{lcccc}
\hline \multirow{2}{*}{ Kelompok } & \multicolumn{2}{c}{ GDP $(\mathbf{m g} / \mathbf{d L})$} & \multicolumn{2}{c}{ TTGO (mg/dL) } \\
\cline { 2 - 5 } & Pre & Post & Pre & Post \\
\hline LKIS & $91,56 \pm 6,46$ & $87,11 \pm 6,92^{*}$ & $95,89 \pm 16,06$ & $95,78 \pm 11,02$ \\
LIIT & $92,11 \pm 6,81$ & $89,11 \pm 8,07$ & $87,89 \pm 11,06$ & $92,11 \pm 12,92$ \\
Kontrol & $92,56 \pm 6,44$ & $91,67 \pm 6,21$ & $94,78 \pm 15,64$ & $89,89 \pm 10,05$ \\
\hline
\end{tabular}

Keterangan: GDP: glukosa darah puasa; TTGO: tes toleransi glukosa oral; *: perbedaan pre-post bermakna (p=0.048 


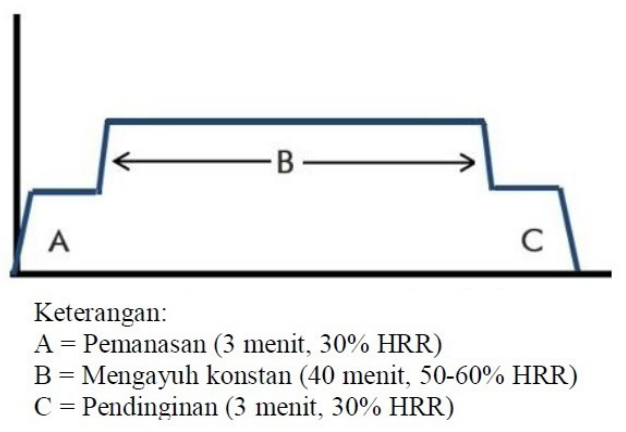

Gambar 1 Bagan Metode LKIS

Hasil pemeriksaan TTGO pada kelompok LIIT menunjukkan kadar glukosa darah rata-rata post-test yang lebih tinggi daripada saat pre-test, sedangkan pada kelompok LKIS dan kontrol saat post-test cenderung menurun. Perbedaan nilai TTGO pre-test dengan post-test di tiap-tiap kelompok tidak bermakna ( $p>0,05)$.

\section{Pembahasan}

Penelitian ini mendapatkan bahwa tidak ada perbedaan GDP dan TTGO yang bermakna antara kelompok LKIS, LIIT, dan kontrol. Namun, pada kelompok LKIS didapatkan penurunan GDP saat post-test yang bermakna.

Pengaruh jenis latihan fisik terhadap kemampuan tubuh meregulasi glukosa darah didasarkan pada beberapa teori mekanisme perpindahan glukosa dari darah ke dalam sel otot dan respons fisiologis tubuh yang timbul karena kontraksi otot saat latihan. Perpindahan glukosa ke dalam sel otot diperantarai oleh protein glucose transporter GLUT-4 secara

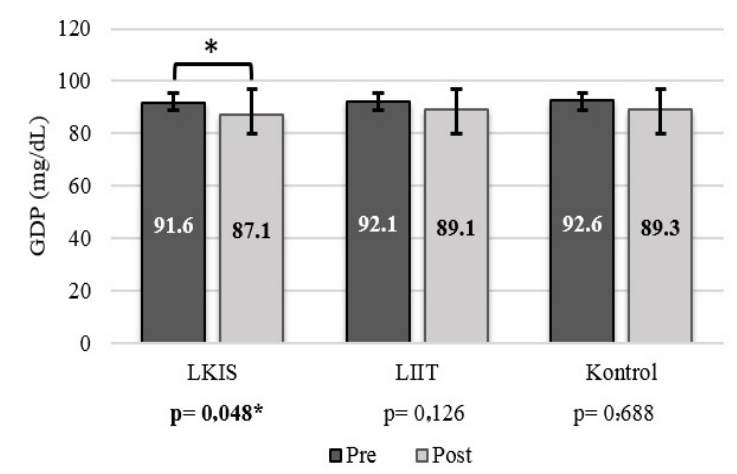

Gambar 3 Hasil GDP Pre-test dan Post-test

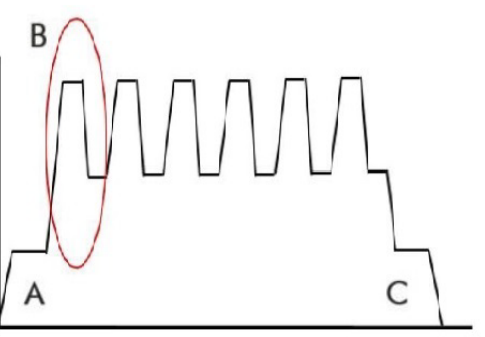

Keterangan:

$\mathrm{A}=$ Pemanasan (3 menit, 30\% HRR)

$\mathrm{B}=1$ siklus LIIT (2 menit $80-90 \%$ HRR +1 menit $50-60 \%$ HRR)

$\mathrm{C}=$ Pendinginan (3 menit, 30\% HRR)

\section{Gambar 2 Bagan Metode LIIT}

difusi terfasilitasi dan mekanisme translokasi GLUT-4 dari intrasel ke sarkolemma dapat dipengaruhi oleh insulin (insulin dependent), atau tidak bergantung pada insulin (non-insulin dependent), yaitu melalui kontraksi otot rangka. ${ }^{12}$ Selain itu, tubuh secara fisiologis merespons latihan fisik sebagai stressor yang membuat otot berkontraksi dan memicu peningkatan respons adrenalin seiring dengan peningkatan intensitas latihan. Latihan dengan intensitas yang tinggi seperti LIIT merangsang tubuh meningkatkan katekolamin yang menghambat kerja insulin dan mengakibatkan pemecahan glikogen otot besar-besaran untuk menghasilkan glukosa sebagai suplai energi kontraksi otot. Glukosa darah meningkat 7-8 kali saat LIIT dan insulin berperan besar pada periode setelah latihan untuk mengembalikan glukosa ke dalam sel otot menggantikan glikogen yang terbuang saat LIIT. $^{5}$ Para peneliti menduga bahwa pengaruh latihan fisik terhadap kontrol glukosa darah ditentukan oleh dosis latihan, terutama dalam hal intensitas dan durasi latihan. ${ }^{12}$

Hasil yang didapat dari penelitian ini berbeda

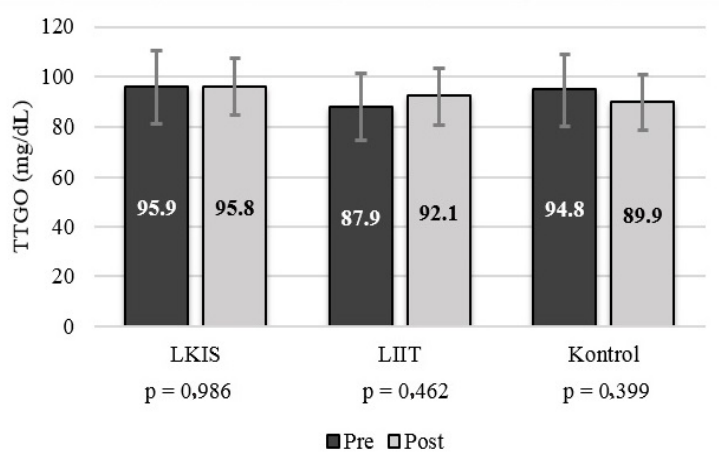

Gambar 4 Hasil TTGO Pre-test dan Post-test 
dengan beberapa penelitian sebelumnya, seperti penelitian Little dkk. ${ }^{6}$ dan Adamson dkk. ${ }^{9}$ yang menemukan bahwa LIIT berpengaruh signifikan terhadap metabolisme glukosa, kemungkinan karena dosis latihan dan subjek pada penelitian ini berbeda. Little dkk. ${ }^{6}$ menerapkan LIIT dengan dosis 10 siklus mengayuh ergocycle selama 60 detik pada $90 \%$ denyut jantung maksimal $\left(\mathrm{HR}_{\text {max }}\right)$ diselingi istirahat selama 60 detik pada subjek DMT2 berusia 60 tahun, sebanyak 6 sesi dalam 2 minggu. Sedangkan prosedur LIIT pada penelitian Adamson dkk. ${ }^{9}$ adalah tanpa pendinginan dan pemanasan, berupa 10 siklus mengayuh sepeda statis sekuat-kuatnya (sprint) selama 6 detik dengan jeda istirahat 60 detik, sebanyak 16 sesi yang terbagi dalam 8 minggu dengan subjek berusia 40 tahun. Penelitian ini mengacu pada prosedur LIIT yang diterapkan oleh Parpa dkk. ${ }^{10}$ dengan sedikit modifikasi pada periode istirahatnya, yaitu dari 2 menit intensitas tinggi +2 menit intensitas sedang pada penelitian Parpa dkk. ${ }^{10}$, menjadi 2 menit intensitas tinggi +1 menit intensitas sedang pada penelitian ini. Periode istirahat yang lebih singkat pada penelitian ini kemungkinan memengaruhi hasil karena waktu pemulihan (recovery) yang kurang optimal untuk menimbulkan respon tubuh yang adekuat. Selain itu, subjek pada penelitian ini merupakan laki-laki muda dan sehat tanpa gangguan kardiometabolik sehingga pengaruh latihan fisik pada subjek ini mungkin kurang signifikan dibanding dengan subjek dengan gangguan metabolik. ${ }^{13}$

Penurunan GDP yang sangat bermakna pada kelompok LKIS pada penelitian ini memperkuat paradigmabahwalatihanintensitassedangsecara teratur dapat meningkatkan kontrol glukosa darah pada subjek yang sehat sehingga relevan untuk menjadi upaya pencegahan penyakit metabolik. Penelitian lain dengan subjek tikus DM yang diberi latihan fisik intensitas ringan-sedang secara teratur pun menunjukkan perbaikan nilai GDP yang bermakna. ${ }^{14}$ LKIS pada penelitian ini menunjukkan hasil yang signifikan kemungkinan dipengaruhi oleh durasi latihan yang lebih panjang dan secara akumulatif memberikan pengaruh lebih besar kepada subjek, meskipun pada intensitas yang lebih rendah daripada LIIT sehingga tampak pada hasil GDP yang berkurang secara signifikan. Beban dan dosis LKIS dan LIIT pada penelitian ini mungkin kurang seimbang sehingga memberikan hasil yang berbeda pula karena ternyata LIIT mempunyai kecenderungan memberikan efek yang setara dengan LKIS saat keduanya memiliki beban latihan yang seimbang/ matched-work basis. ${ }^{4}$ Selain itu, latihan dengan intensitas tinggi pun dapat dikaitkan dengan motivasi individu karena tanpa motivasi yang cukup seringkali mengakibatkan individu gagal mencapai intensitas dan volume latihan yang diinginkan agar LIIT dapat memberikan hasil optimal. ${ }^{15,16}$

Penelitian lain dengan subjek laki-laki sehat dilakukan oleh Babraj dkk. ${ }^{7}$ berupa 6 sesi LIIT yang tersebar dalam 2 minggu, berupa 4-6 siklus x30 detik ergocycle sprint dengan periode istirahat selama 4 menit antarsiklus, pun tidak menunjukkan perubahan GDP yang bermakna. Namun pada penelitian tersebut menemukan kecenderungan peningkatan toleransi glukosa dan sensitivitas insulin yang diperiksa 48 atau 72 jam setelah latihan LIIT terakhir. ${ }^{7}$ Peningkatan toleransi glukosa dan juga sensitivitas insulin diketahui melalui TTGO dengan pemeriksaan glukosa plasma secara berkala sebelum dan setelah pemberian beban glukosa $(60,90$, dan 120 menit) dan pemeriksaan plasma insulin pada menit ke-0, 60, dan 90 setelah pemberian beban glukosa. ${ }^{7}$ Dengan pengambilan data TTGO secara berkala tersebut, Babraj dkk. ${ }^{7}$ melaporkan ada penurunan luas area di bawah kurva (area under the curve-AUC) yang menunjukkan peningkatan toleransi glukosa setelah LIIT. Sensitivitas insulin perifer pada penelitian tersebut dihitung dengan formula Cederholm Index yang juga menunjukkan ada perbaikan yang bermakna. ${ }^{7}$ Peningkatan sensitivitas insulin merupakan efek dari pemanfaatan glikogen otot yang besar saat LIIT sehingga memicu kinerja insulin yang lebih baik pada periode pasca latihan untuk mengembalikan cadangan glukosa dalam otot. ${ }^{17,18}$

Pada penelitian ini hanya didapatkan data TTGO 120 menit sesudah pemberian beban glukosa, yang memungkinkan kadar glukosa darah sudah kembali normal, sehingga informasi yang didapatkan kurang komprehensif dan tidak dapat diketahui AUC-nya. Selain itu, pemeriksaan sensitivitas insulin pada subjek yang sehat mungkin akan memberikan informasi yang lebih jelas untuk mengetahui kemampuan regulasi glukosa subjek setelah pemberian intervensi program latihan fisik, akan tetapi sensitivitas insulin tidak diperiksa pada penelitian ini. Hal seperti inilah yang menjadi keterbatasan pada penelitian ini. Selain itu, tidak dilakukan pengaturan diet untuk subjek pada penelitian ini pun kemungkinan membuat hasil yang kurang jelas, apakah hasil yang diperoleh benar-benar disebabkan oleh program latihan atau tidak.

Simpulan, LKIS selama empat minggu pada subjek dewasa muda dan sehat telah tampak 
memberikan pengaruh yang nyata untuk dapat meningkatkan kontrol glukosa darah, akan tetapi masih perlu diteliti lebih lanjut dengan modifikasi dosis LIIT untuk lebih memastikan pengaruh LIIT terhadap kontrol glukosa darah. Penelitian terkait LIIT dan LKIS yang telah dilakukan di berbagai negara dengan metode dan dosis latihan yang bervariasi telah memberikan banyak informasi yang penting, tetapi belum ada kesepakatan terkait metode dan dosis latihan yang terbaik untuk memberikan hasil yang optimal. Masih diperlukan penelitian lebih lanjut dan lebih saksama tentang pengaruh LIIT dan juga LKIS terhadap berbagai fungsi metabolik tubuh agar upaya pencegahan penyakit pada metabolik dapat ditingkatkan.

\section{Daftar Pustaka}

1. American Diabetes Association (ADA). Standards of medical care in diabetes-2015. Diabetes Care. 2015;38(Suppl 1):1-94.

2. Ramachandran A, Snehalatha C, Shetty AS, Nanditha A. Trends in prevalence of diabetes in Asian countries. World J Diabetes. 2012;3(6):110-7.

3. Colberg SR, Sigal RJ, Fernhall B, Regensteiner JG, Blissmer BJ, Rubin RR, dkk. Exercise and type 2 diabetes. Diabetes Care. 2010;33(12): 2692-6.

4. Gibala, MJ, Little JP, MacDonald MJ, Hawley JA. Physiological adaptations to low-volume, high-intensity interval training in health and disease. J Phyisiol. 2012;590(5):1077-84.

5. Adams OP. The impact of brief high-intensity exercise on blood glucose levels. Diabetes Metab Syndr Obes. 2013;6:113-22.

6. Little JP, Gillen JB, Percival ME, Safdar A, Tarnopolsky MA, Punthakee Z, dkk. Lowvolume high-intensity interval training reduces hyperglycemia and increases muscle mitochondrial capacity in patients with type 2 diabetes. J Appl Physiol. 2011; 111(6):1554-60.

7. Babraj JA, Vollaard NBJ, Keast C, Guppy FM, Cottrell G, Timmons JA. Extremely short duration high intensity interval training substantially improves insulin action in young healthy males. BMC Endocr Disord. 2009;9(3):1-8.

8. Richards JC, Johnson TK, Kuzma JN, Lonac MC, Schweder MM, Voyles WF, dkk. Shortterm sprint interval training increases insulin sensitivity in healthy adults but does not affect the thermogenic response to $\beta$-adrenergic stimulation. J Physiol. 2010;588(15):2961-72.

9. Adamson S, Lorimer R, Cobley JN, Lloyd R, Babraj J. High intensity training improves health and physical function in middle aged adults. Biology. 2014;3(2):333-44.

10. Parpa KM, Michaelides MA, Brown BS. Effect of high intensity interval training on heart rate variability in individuals with type 2 diabetes. J Exerc Physiol Online. 2009;12(4):23-9.

11. Jamaluddin FA, Gunavathy M, Yean CY, Thevarajah M. Variability of point-ofcare testing blood glucometers versus the laboratory reference method in a tertiary teaching hospital. Asian Biomed. 2012;6(1):67-74.

12. Richter EA, Hargreaves M. Exercise, glut4, and skeletal muscle glucose uptake. Physiol Rev. 2013;93(3):993-1017.

13. Numao S, Kawano $H$, Endo $N$, Yamada $Y$, Konishi M, Takahashi M. Effects of a single bout of aerobic exercise on short-term low-carbohydrate/high-fat intake-induced postprandial glucose metabolism during an oral glucose tolerance test. Metab Clin Exp. 2013;62(10):1406-15.

14. Zulkarnain, Satria D, Yus TM, Rezeki S. Pengaruh latihan fisik teratur terhadap kadar glukosa darah dan hubungannya dengan kadar testosteron total pada tikus model diabetes. MKB. 2015;47(1):16-21.

15. Feo DP. Is high-intensity exercise better than moderate-intensity exercise for weight loss. Nutr Metab Cardiovasc Dis. 2013;23(11):1037-42.

16. Lunt H, Draper N, Marshall HC, Logan FJ, Hamlin MJ, Shearman JP, dkk. High intensity interval training in a real world setting: a randomized controlled feasibility study in overweight inactive adults, measuring change in maximal oxygen uptake. PLoS ONE. 2014;9(1):e83256.

17. Roberts CK, Hevener AL, Barnard RJ. Metabolic syndrome and insulin resistance: underlying causes and modification by exercise training. Compr Physiol. 2013;3(1):1-58.

18. Francois ME, Little JP. Effectiveness and safety of high-intensity interval training in patients with type 2 diabetes. Diabetes Spectr. 2015;28(1):39-44. 